\title{
Recent Work on Aristotelian Biology
}

\section{Marjorie Grene}

Virginia Tech

The past several decades have seen a proliferation of scholarly work on Aristotle's biological writings. The recent publication of James Lennoz's collected essays, Aristotle's Philosophy of Biology, seems a fitting occasion to look at some aspects of this literature, since he, together with his co-worker Allan Gotthelf, has been one of its most conspicuous contributors. The proceedings of a conference on Aristotelian biology, held at Bad-Homburg in 1995, and published in 1997 under the editorship of Wolfgang Kullmann and Sabine Föllinger, includes essays by a representative group of such specialists. G.E.R. Lloyd's Aristotelian Explorations of 1996, though not entirely concerned with the biology, does deal principally with this area; and a more recent work by Kullmann, published in 1998, Aristoteles und die moderne Wissenschaft, though more ambitions in its overall aims, also bears in large part on the interpretation of the biological writings. Without attempting to delve into the periodical literature (which, for those interested, seems to be pretty well covered in the bibliographies of the works in question), I shall present some of the issues for the interpretation of Aristotle's biological works raised in these volumes. ${ }^{1}$

In part, the work in question has served chiefly to illuminate the texts, a telos that is always worth pursuing for a thinker as complex and often as obscure as Aristotle. Before I proceed to more controversial questions, let me just mention a few of these cases. Both Lloyd and Lennox, for example, take up the problem of spontaneous generation in Aristotle (in Lloyd's

1. James G. Lennox, Aristotle's Philosophy of Biology: Studies in the Origins of Life Science, Cambridge: Cambridge University Press, 2001; Wolfgang Kullmann and Sabine Föllinger, Aristotelische Biologie: Intentionen, Methoden, Ergebnisse, Stuttgart: Franz Steiner Verlag, 1997; G.E.R. Lloyd, Aristotelian Explorations, Cambridge: Cambridge University Press, 1996; Wolgang Kullmann, Aristoteles und die moderne Wissenschaft, Stuttgart: Franz Steiner Verlag, 1998.

Perspectives on Science 2000, vol. 8, no. 4

(C) 2001 by The Massachusetts Institute of Technology 
case including the related problem of metamorphosis). One way to put the question is to ask how what is chancy or "spontaneous," and by definition rare, can produce regular results. Another is to ask how reproduction, or something analogous to it, can eventuate from processes that, in terms of Aristotle's usual causal thinking, lack the end-directedness characteristic of generation in the "normal" case. Although the two writers present different resolutions of these problems, they both lead us to reflect on some of the complexities of Aristotle's biological thought. Similarly, Lloyd's examination of the varieties of perception exhibits perplexing details in Aristotle's accounts of this activity, characteristic for all animals, especially with respect to the basic and most pervasive of the senses, that of touch. Lennoz presents a coherent and illuminating reading of the History of Animals - if we take it apart from his chief methodological thesis, to which I shall return. And he makes what seems to me a most useful suggestion with respect to the rendering of the terms eidos and genos. Following the lead of David Balme, who showed in his ground-braking studies that Aristotle used these concepts in his biological works, not in something like the Linnaean sense of "species" and "genus," but at numerous, seemingly arbitrary ranges of reference, Lennox suggests that we render the terms denoting them regularly as "form" and "kind," abandoning the misleading distinction between eidos" "form" and eidos' "species" which was introduced in the Latin tradition, and stressing what appear to be their original meanings: one to do with the operating principle of a natural entity, and the other with its kin or family, its line of descent. (Unfortunately, Lennox himself does not stick to this practice.) I should also add that Kullmann, in his ambitious book, takes definite issue with this reading; I'm afraid in this case I agree so definitely with Lennox's position, which certainly accords with the view of most Aristotelian scholars, that I cannot count this disagreement among the issues we need to look at.

The participants in the Bad Homburg conference also present illuminating contributions to some special interpretive problems. Again, let me mention just a few. Two basic concerns in reading Aristotle on living things are, on the one hand, his concept of teleology, and on the other, the role of matter in "composites," that is, entities characterized by their formal natures, yet necessarily enmattered. Alan Code writes on "The Priority of Final Causes Over Efficient Causes in Aristotle's PA," and David Charles's inquiry, "Aristotle and the Unity and Essence of Biological Kinds" also deals, necessarily, with the question of teleology. Several papers deal with the other side of the problem: matter and the material cause-apart from Charles, Robert Bolton, Mary Louise Gill and Lennox deal explicitly with this question, Gill in the context of the Meteorology IV 12 , but with a clear bearing on the interpretation of the biological work. 
(Lennox's paper on "Material and Formal Natures in Aristotle's De Partibus Animalium" is also reproduced in his own collection.) Kullmann's contribution, "Die Voraussetzungen für das Studium der Biologie bei Aristoteles," though much more ambitious in its overall intent, does also deal with the role of matter in this context. I shall refer to it again later; here I just want to acknowledge the existence in the texts before us of numerous illuminating analyses which I must perforce neglect in turning to what seem to me large issues that our authors leave open for debate.

It should come as no surprise, that, like most historical undertakings, at least any with philosophical underpinnings or implications, our texts raise issues of interpretation that are still subject to controversy. Two very general, and at the same time fundamental, questions need to be considered. First, how does Aristotle's methodological program, especially as presented in the Posterior Analytics, relate to the practice reported in the biological works? And second, how is Aristotle's science related to the theory and practice of his modern successors? There are also some less global issues glanced at in these texts, which may or may not be related to the larger issues. I will turn to those briefly in conclusion.

First, then, how rigorously does Aristotle the biologist follow the dictates of Aristotle the methodologist? It is Lennox's major thesis that the latter follows the former very closely indeed. It is Lloyd's major thesis that he does not. For Lennox, the discoverer of the tools of philosophy takes care to apply those tools properly and consistently as he executes and expresses the outcome of his scientific work. There is only one Aristotle, the supreme methodologist who applies that methodology consistently in his study of the natural world. For Lloyd, a more tentative and experimental Aristotle shows above all a remarkable "sense of the interdependence of philosophical analysis and empirical investigation" (p. 137). Yet, he insists, although the two interests work together, we should be careful to distinguish between "Aristotle the logician" and "Aristotle the field-worker" (p. 73). There are at least two Aristotles, maybe a host of them, and that is just why the range of work done under the name of this one, yet manifold, thinker is so fascinating. Plato talked about the one over many. In this case, which is it: the one controlling the many, or the many enriching the apparent one?

As a relative outsider to this dispute, who has worked only briefly and long ago (with the most welcome and generous help of David Balme) on a particular technical aspect of Aristotle's philosophy of biology-as a relative outsider, I confess to having an answer, at least a partly evasive answer, to that question. But first let me try to summarize the two points of view as fairly as I can. 
Although Lennox's essays cover a period of twenty years, they are all, he tells us in the introduction to the volume, addressed in some way to what he calls "an exciting possibility," namely, "that [Aristotle's] zoology reflects the recommendations of his philosophy of zoology, and that his philosophy of zoology reflects his general philosophy of science" (p. xxii). There are, he confesses, problems in the way of actualizing that possibility. For example, there is the absence of any discussion of form and matter in the methodological treatises - concepts fundamental to the work in natural history. Nor is there any cross-reference from the philosophical essays introductory to the biology, that is, the first book of the Parts of Animals, to the more general methodological works. Further, division is treated differently in those two texts. There are also apparent discrepancies between the programmatic statements of $P A$ I and the detailed biological works themselves. However, Lennox concludes, "[e]ach of the chapters in this volume contributes to the task of overcoming these various problems, and thus to presenting a unified version of Aristotle's philosophy of biology as carrying out, in a specific domain of natural science, the philosophical program of the Posterior Analytics. This involves considerable enrichment of that program, but not an abandonment of it" (p. xxiii). It would be unkind to say that Lennox is obsessed with this task; it is certainly a major intellectual preoccupation, one could even call it his vocation. Kullmann, in his Bad Homburg paper, in effect agrees with this position, since he holds that Aristotle's biological work supplements the more mathematically oriented exposition of the Organon by adding the necessary reference to matter. Along with the stress on final cause, that would, I presume, be the kind of "enrichment" of the program that Lennox has in mind.

It is the essays of Part One of Lennox's collection, "Inquiry and Explanation," that deal most explicitly with the author's major thesis. The first, "Divide and Explain," relies in particular on Aristotle's advice to the scientist in Posterior Analytics II, 14: he is to

... select thus, positing the kind common to all, e.g., if the subjects of study are animals, [select] what follows all animals, and having grasped these, again what follows all the first remaining things, e.g., if this is bird, what follows every bird, and thus always [ask what belongs] to the nearest kind (98a 2-8; pp. 13-14).

Without our going into the particulars of Lennox's careful analysis here, it should be clear that Aristotle is recommending that the practitioner of natural history should start with a rather general common kind, and carefully focus in on a more restricted kind, in which he can find differentiae that follow from the very nature of that kind. That will be proper Aristo- 
telian explanation. As I mentioned earlier, Lennox illustrates this endeavor through looking at the overall aims of the History of Animals, and also at a number of passages in the Parts of Animals. He has discovered, he tells us in conclusion, "[a] number of lines of evidence suggesting deep affinities between the theory of explanation and understanding in the Apo and the zoological treatises" (p. 32).

The History of Animals is again the focus of the second essay, "Data and Demonstration," in which that treatise is shown to be narrowing in on the differentiae of appropriate units. The later biological treatises will then proceed to demonstrate their causes. This is, Lennox argues, "the first step toward causal accounts in the explanatory model proposed in the Posterior Analytics" (p. 65). The third essay examines the nature of problems in Aristotle, a technical concept that had been touched on in the first chapter. Finally, the fourth chapter "Putting Philosophy of Science to the Test: The Case of Aristotelian Biology," is intended to show definitively how Aristotle's philosophy of science is applied, with due specification and elaboration, first, in Book One of the Parts of Animals, which is in effect a philosophical introduction to the biological works, and then, through the detailed analysis of an example, in the scientific books that follow. The analysis of Book One involves back references to passages in the Analytics, Prior as well as Posterior, while granting that the concept of conditional necessity, absent from the general methodological treatises, has had to be added to deal with the subject matter of the life sciences. The example chosen to illustrate Aristotle's scientific practice is that of the fat surrounding the kidneys. Lennox uses this case to show how causes are exhibited through syllogistic explanation, and how in particular, for living things, the final cause takes primacy - though never, of course, eliminating the concomitant references to matter. If there appears to be a question how a methodological treatise based primarily on mathematical examples can be applied to living things, demanding as these do explanations grounded in teleology, PA I, Lennox concludes, answers this question, and, further, that answer is borne out in detail in Aristotle's actual biological practice. The overall lesson is that it is Aristotle the logician who guides Aristotle the zoologist.

For Lloyd, as we noted, the contrary is the case. Indeed, Lloyd is not even sure of a single, well-defined character for the theorist of scientific method, who is supposed to have told us what a demonstration is and how to produce one. In an essay "On the theories and practices of demonstration," he exhibits, through careful citation, the range of senses of "demonstration" in Aristotle's works, works as diverse as the Rhetoric, the Ethics, the Metaphysics. It is not so clear, according to him, that there is just one univocal kind of demonstration to serve as model for the natural scientist, 
certainly not the model set up at the start of the Posterior Analytics, in which primary, indemonstrable premises must stand at the head of scientific explanation. The biological works themselves provide some of his examples, and $P A \mathrm{I}$, in particular, Lloyd concludes, far from following the rules set up in Apo, "uses end-products as its starting-points and works back to their conditionally necessary starting-points" (pp. 36-7).

At first sight it looks as if Lloyd is keen on following the opening chapters of the methodological text, while Lennox (who reproaches his colleagues for neglecting the later chapters) concentrates on Book II, 14-18. But there is more to it than that: in the essays that follow the opening critique of "demonstration," Lloyd repeatedly stresses, not the rigor of Aristotle's method, but his openness: his willingness, as a field biologist, to hesitate, to qualify his own doctrines, to see problems in applying principles too sweepingly, or too univocally. For example, in an essay on "Fuzzy Natures," in which he considers some cases where Aristotle has trouble determining, by his usual criterion of perception, whether he is dealing with a plant or an animal, Lloyd concludes:

... the situation may be the following: it is only when Aristotle confronts some of the really difficult cases directly that he has grounds for hesitation and (on this suggestion) may be led to modify his usual view. Generally speaking, and for most purposes, the perception criterion will do and can be spoken of as the key determining characteristic. After all the definite exceptions to that rule amount just to the jellyfish and holothouria, even though, as he also notes, other animals give no indication, or only a faint one, of perception, and in some cases one can grasp no other function besides generation. Yet when faced with those problematic creatures in the sea, Aristotle-on this suggestion - is prepared to revise his idea of what an animal is.

The lesson is that

... for those who give full weight to the signs of hesitation where he has good reason to hesitate-for as we said it is no easy matter determining the borderline-this is testimony to the flexibility of his work as a zoologist and indeed his open-mindedness (p. 82).

Although the collection explores a wide variety of topics, from demonstration to analogy and metaphor, it is this notion of Aristotle the explorer, the risk-taker in zoological investigation, that guides Lloyd's own explorations. If, as we acknowledged earlier, Lloyd gives due obeisance to the "interdependence of philosophical analysis and ... empirical investigation" 
(p. 137), it is Aristotle the practicing zoologist, even the puzzled zoologist, who most interests him.

How, as readers, are we to adjudicate this issue? As I confessed earlier, I do have an answer, though a rather qualified one.

On the one side, I hesitate to follow Lennox, for a number of reasons. First, as Lloyd points out, we do not have those first, indemonstrable premises that the Analytics demands. In a way Lennox is showing, in his analysis of the $H A$, how Aristotle zeroes in on a subject matter that is "commensurately universal": applicable to just this range of phenomena and no more. But we certainly are not given fundamental first principles, both exactly circumscribed and grasped by nous, a faculty superior to the capacity for demonstrative knowledge. Lennox questions whether our knowledge really needs to be like that - though the master certainly said it did. He thinks we will be behaving sufficiently in accord with Aristotle's instructions if we translate his explanations into syllogistic form (although at the close of his first essay he seems to be questioning that, too; see p. 33). If, however, syllogistic form was so important, one wants to ask, why didn't Aristotle use it himself? Why did he write treatises that appear largely inductive or dialectical rather than demonstrative, at least in the sense of being explanatory through the specification of a middle term? Leaving that question aside, however, what I find most worrying is what happens when one does put Aristotle's explanation into his canonical form. Far from exhibiting Aristotle's prowess as a biologist (which I am far from wishing to deny), I find, for example, that the translation into syllogistic form of the account of kidney fat makes it look rather trivial than otherwise. The ne plus ultra of this procedure is to be found in Allan Gotthelf's essay in Aristotelian Biology, "The Elephant's Nose," where, in my view, a long and painstaking analysis of an Aristotelian text reduces it to just the kind of non-explanatory nit-picking that early modern Aristotelians were so often accused of. What has happened to the great naturalist, that indefatigable observer, who watched the male catfish up in Thrace guarding his young for forty days - a behavior unlikely for an Aristotelian male, and which was not credited until a couple of millennia later, when the critter was christened, in honor of its discoverer, Parasilurus aristotelis? No, I'd much rather start with the zoology, as Lennox himself, in a footnote, suggests one might do (p. 66, n. 3), and see some reflection of Aristotle's biological interests in his philosophy: the metaphysic as well as the philosophy of science.

From that point of view, Lloyd's explorations are refreshing. Here, too, however, I do have some problems. Is Aristotle as thoroughly "open-minded" as Lloyd suggests? Looking at the corpus as a whole, one is impressed by the way he tackles a subject matter, admittedly, with due at- 
tention to difficulties, but in the spirit of one who intends to work his way through it, tidy it all up, and go on to the next job. After all, if you want to produce a good argument, whether logically, dialectically, or rhetorically, you have in each case a book of instructions: the Analytics, the Topics, and the Rhetoric respectively, to show you how. If you want to lead a good life or write a good tragedy, again, you've got a nice neat set of instructions ready to hand. Not, in my view, that this contradicts Aristotle's biological interests. On the contrary, it is just the frame of mind one might expect to find in a devoted practicing naturalist, who wants to see just how this works, to separate this from that, and try to grasp the very nature of just this kind and no other. In 1830, Georges Cuvier was proud to celebrate Aristotle as the founder of comparative anatomy, precisely because he had understood that each organism is made for itself-no sweeping generalizations across everything at once, such as Geoffroy Saint-Hilaire claimed to have found. It is this life-style, this harmonious subordination of characters, for the end of coming to be this kind of animal, that the comparative anatomist is after. And in mapping out a model for the sciences, it seems to me that Aristotle was at least partly moved by that naturalist's propensity to divide and conquer, in Lennox's phrase, to divide and explain. Further, though that is only very peripherally in question in this discussion, it was clearly Aristotle's primary interest in living things that slanted his metaphysics in the direction it took. Whatever one's view of the much analyzed Book Zeta, it is plain that for Aristotle living beings are the most interesting, the most characteristic, instances of substance. So, while acknowledging interaction between the two- practice and theory-let us, on the whole, put practice first.

The second major issue we need to raise concerns the relation of Aristotle's science to ours. Insofar as our authors are trying, as best they can, to read Aristotle in his own terms, there is no problem here. It is a question of using the tools of careful linguistic, historical and philosophical scholarship to further our understanding of a thinker speaking to us in a different tongue and from a different culture, though, indeed, one in part continuous with ours. Sometimes, as Lloyd suggests, one would also like "not just to take his work seriously, but to learn from it." That, as he puts it, is an "entirely laudable desire," yet it has its dangers. As Lloyd continues, it "has to be done without assuming that he is one of us (whoever 'we' are) or that his thought is somehow disembodied and timeless" (p. 2). We may take that statement as representing one side of the issue here. Lennox, too, although he does seem to want Aristotle to be not only interesting, but right, wherever possible, also admits that we can learn philosophically as much from understanding our differences from him as we can from understanding the "affinities" between us (p. xx). So perhaps we can place 
Lennox, also, if with qualifications, on the side of those who recognize the historical distance that separates students of Aristotelian biology from their subject.

Squarely on the other side-and that is what makes this so plainly an issue-we have Wolfgang Kullmann's massive tome, Aristoteles und die moderne Wissenschaft, which seeks to base the whole of modern science, including social science ('Wissenschaft' taken in its broad German sense), on concepts and principles discovered by Aristotle. Where moderns disagree with the master of all who know, they are mistaken; where they are correct, of course they are bound to agree with him. There are students of Aristotle who assimilate him to modern ways of thinking, who write of Aristotelian epistemology or philosophy of language. Even Lloyd, scrupulous historian though he is, errs somewhat, it seems to me, in worrying about Aristotle's "philosophy of mind." Is it or isn't it functionalist? The whole Problemstellung appears to me inappropriate. But what is one to call the contrary of Whiggishness, where, instead of assimilating an earlier thinker to our interests, we try hard to reduce our concerns to his? Whatever we call it, it does exist: Kullmann gives a 450 page example of it.

It is "Aristotle's significance for modern science" ("Aristoteles' Bedeutung für die moderne Wissenschaft") that is his overall theme. Scientific knowledge, he believes, moves in the form of a spiral, so that a formerly established paradigm can return, perhaps with more factual backing at its disposal, but still essentially the same as in its first occurrence. This conception of "alternating paradigm change" he contrasts with what he takes (astonishingly) to be Thomas Kuhn's conception of a linear advance from worse to better as paradigms shift. Modern science, though, to be sure, accumulating a lot of additional factual underpinning, has now triumphantly returned to its original, true, solid Aristotelian foundations (p. 29). Let me look at a number of the theses incidental to that overall theme.

To begin with, Kullmann enumerates a number of terms we have retained from Aristotle: category, necessity, induction, etc., etc. "Substance and matter," for example, he concludes, "are physical-chemical basic concepts" (pp. 28-9). But in what sense is a modern chemical substance an Aristotelian ousia? And Aristotelian matter, which cannot conceivably exist on its own: has it survived the depredations of Descartes and his successors? However, that is only the first of the shocks to which Kullmann subjects his readers. There is much more to come; I can only sample it here.

For one thing, it was Aristotle, it seems, who originated "the conception of bipartite science" ("Die Konzeption der zweigeteilten Wissenschaft"), to which we still subscribe. For it was Aristotle who first distinguished induction and deduction (or demonstration) as the two 
phases of scientific research. In Aristotle's finite, forever cycling cosmos, however, I should have thought, induction is a nice neat, relevantly first step toward the grasp of the principles of science. For post-Humeans, it is a process that tries to move from potentially infinite data to necessarily finite conclusions, a much chancier undertaking. And in any case, the logical distinction induction/deduction, while it may have been pertinent to philosophy of science in the bad old days of logical empiricism, surely is of little import in more recent, and more historically enlightened, studies of scientific practice.

Further, in the course of an exposition of Aristotle on tissues and organs, Kullamnn refers to the "mixed bodies" of the Generation and Corruption (II 8, 334 b 31f.) as "chemically joined bodies" ("chemisch verbundene Körper'; p. 180) and proceeds to celebrate Aristotle's grasp of "the idea of chemistry." He writes:

We see how Aristotle, speculatively indeed, yet with the right approach, first grasped the 'idea of chemistry' . . . It is astonishing ... that he could develop the principle of chemistry, without being able to have access to modern methods of measurement and experiment (p. 181). ${ }^{2}$

This is all, one assumes, because Aristotelian "compounds" have properties different from those of their constituents, as water has properties different from those of hydrogen and oxygen. But, please, Aristotle's elements are composed of four qualities, hot, cold, moist and dry, and the conception of a world made primarily of qualities is utterly alien, or so it seems to me, to any modern way of thinking. Nature, Galileo taught us, for good or ill, is written in the mathematical language. A nature in which things are actually the way they are at bottom because they are hotter or colder, moister or drier, is really very hard for us to grasp. If the particles in a substance (our kind of substance!) move faster, it gets hotter-not the other way around. Surely John Dalton was closer to Leucippus or Democritus than to Aristotle!

It appears, also, that "Aristotle's pronouncements on natural science already fulfill in many areas essential criteria that we still demand today of natural laws" (p. 244). ( . . . dass Aristoteles' naturwissenschaftliche Aussagen in vielen Bereichen wesentliche Kriterien, die man heutzutage an Naturgesetze stellt, bereits erfüllen.) This takes a bit of stretching, but

2. Man sieht, wie Aristoteles, skepulativ zwar, aber doch mit richtigem Griff, erstmals 'die Idee der Chemie' erfasst hat. Erstaunlich ist . . . dass er das Prinzip der Chemie entwickeln konnte, ohne über die modernen Mess- und Experimentiermethoden verfügen zu können. 
never mind. On the other hand, Aristotelian teleology is of course readily assimilable to the concept of teleonomy introduced by C.S. Pittendrigh and elaborated by Ernst Mayr (pp. 302-306).

But we are by no means finished. Short of the lengthy treatment of political thought, which would take us too far afield (though I may just note that in this case all who consider man a political animal are Aristotelian and good, and all who talk of social contracts are anti-Aristotelian and bad), and of a briefer account of approaches to a theory of communication in the Rhetoric, we have two shockers to come.

First, there is Aristotle's 'epigenetic' embryology, opposed, as usual, to its un-Aristotelian and unenlightened opposite, the idea of preformation, frequently exhibited, according to Kullmann, in numerous figures in the history of biology, from Democritus to Darwin and Weismann. He notes that the term "epigenesis" was introduced by Harvey, a good many centuries later, but, he is confident, the guiding principle is already there in Aristotle's theory of development. Oddly, he likens Aristotle's account both to Haeckel's biogenetic law, and to the very different concept of von Baer, which he calls the "preliminary form" (Vorform) of that law (p. 286). Kullmann is not the only one to call Aristotle an epigeneticist, but I must confess I find this thesis surprising. After all, if only potentially, but somehow worked up sufficiently to impose itself on the relatively inert female matter, the form of the male parent has got to be there as the agent of development. In fact, if only incidentally, in rejecting preformation in the development of single organs (where we have instead something like a mechanical chain reaction), Kullmann himself refers to the way in which the form of the son is present in the father ("die [Form] des Sohnes im Vater" p. 285). Is that epigenesis? Not to my way of thinking.

The epigenesis-preformation debate, however, belongs primarily to the eighteenth century. Given the advent of modern genetics, one can take development either way: a single cell develops into many differentiated cells, but that single cell contains instructions that govern the development to come. Epigenesis or preformation? Ernst Mayr says it is obvious that once you have a genetic code, you have preformation (personal communication). Kullmann clearly wants it the other way. At the same time-together with his epigenetic story-he wants to find in Aristotle the conceptual foundations of genetics, complete with a genetic code-yes, I really wrote that, and so did he. In the initial summary of his argument he writes:

Aristotle's genetics, seen as an abstract model, has an extraordinary similarity to the modern theory of molecular biology, which has to 
do with DNA and the genetic code. Thus Aristotle's point of view is not, indeed, superior to modern knowledge, in relation to which it lags far behind in detail, but it is more balanced than the picture of embryology and genetics in the first half of our century. The example shows that the cumulative increase of detailed knowledge does not guarantee the correct total conception, the decision for the right model (pp. 32-33). ${ }^{3}$

He expands on this declaration in due course in a section on "Aristotle's Reflections in the Area of Genetics: The Application of his Craft Model" ("Aristoteles' Überlegungen auf dem Gebiet der Genetik. Die Anwendung seines Technemodells"; pp. 387-300).

Of course Aristotle was handicapped by the fact that the female ovum of mammals was discovered only in the nineteenth century (p. 290). Even here, Kullmann insists, Aristotle modified his position sufficiently to give both parents a role (loc.cit.). He proceeds to summarize Aristotle's account of generation, in which the work of the seed introduced into the female matter is likened to that of the carpenter initiating the building of a house. The building itself can go on relatively mechanically, once the male has introduced the impulse to human-hood into the catamenia. Kullmann continues:

This means, therefore, that all the hereditary Anlagen of the male, which move to the female, are transferred in encoded form, that is, in the form of impulses to movement, from the seed to the catamenia present in the female uterus, while the seminal fluid itself is vaporized. . . . Thus all the hereditary Anlagen (that is, the whole genetic 'program') are at the same time encoded in the whole blood of every human individual (and therewith in his seed) in the form of wave-like movements" (p. 294). ${ }^{4}$

3. Aristoteles' Genetik hat . . . als abstraktes Modell betrachtet eine ausserordentliche Ähnlichkeit mit der modernen Theorien der Molekularbiologie, die die DNS und den genetischen Code betreffen. Aristoteles' Standpunkt ist also zwar nicht modernen Erkenntnisen überlegen, hinter denen er im Detail undenklich weit zurückbleibt, aber er ist ausgewogener als das Bild von Embryologie und Genetik in der ersten Hälfte unseres Jahrhunderts. Das Beispiel zeigt, dass die kumulative Steigerung von Detailwissen noch nicht die richtige Gesamtsicht, die Entscheidung für das richtige Modell, verbürgt.

4. Dies bedeutet also, dass alle Erbanlagen des Männchens, die auf das Weibchen übergehen, in codierter Form, nämlich in Form von Bewegungsimpulsen, vom Samen auf die im weiblichen Uterus befindlichen Katamenien übertragen werden, während die Samenflüssigkeit selbst verdampft . . . Alle Erbanlagen (d.h. das ganze genetische 'Programm') sind somit im ganzen Blut eines jeden Menschen (und damit in seinem Samen) in Form von Wellenbewegungen codiert. 
The text Kullmann cites here, 737a11, is in the Generation of Animals II, 3, a paragraph in which Aristotle discusses the "body" of the semen, apart from its soul (though, except in the case of nous, they are inseparable). He describes how it dissolves and evaporates, and how we should not expect to find it as an ingredient in the developed fetus "any more than we should expect to trace the fig-juice which sets and curdles milk" (737a15; Loeb translation). What this has to do with a genetic code I really fail to see; however often I read Kullmann's argument and however often I consult Aristotle's text, the parallel still escapes me. Yet Kullmann concludes his argument by assuring us even though, due to the absence of microscopes and for other reasons as well, Aristotle did indeed miss many basic insights, "in many particulars, which have here been treated only very incompletely, his explanations have been shown to be correct over against much newer conceptions, even till today” “ “. . [seine Erklärungen] haben sich in zahlreichen Einzelpunkten, die hier nur ganz unvollständig angesprochen würden. . . gegenüber viel jüngeren Vorstellungen sogar bis heute als richtig erwiesen” p. 299).

Reading all this, I keep thinking, but the genetic code was not discovered until 1953. No embarrassment to Kullmann: he is well prepared. His section on "The Contemporaneity of Aristotelian Biology in the Field of Embryology and Genetics" ("Die Aktualität der Aristotelischen Biologie im Bereich der Embryologie und Genetik" pp. 301-312) concludes:

Only with modern molecular biology has a theoretical level been achieved that is true to the phenomena. In 1953 J.D. Watson and F.H. Crick developed the model of the double helix, which allows us to understand the mechanism and the structure of DNA and the function of the genetic code. Despite the infinite distance in detailed knowledge between Aristotle and modern biology, the conviction is common to both that the hereditary Anlagen are present in the whole body (whether in the blood or in the genes in every cell), but that they are transferred in encoded form to the developing seed (pp. 311-312). ${ }^{5}$

5. Erst mit der modernen Molekularbiologie ist wieder ein theoretischer Niveau erreicht, das den Erscheinungen gerecht ist. 1953 entwickelten J.D. Watson and F.H. Crick das Modell der Doppel-Helix, das es uns erlaubt, den Mechanismus und die Struktur der DNS und die Funktion des genetischen Codes zu verstehen. Trotz des unendlichen Abstands im Detailwissens zwischen Aristoteles und der modernen Biologie ist beiden doch die Überzeugung gemeinsam, dass die Erbanlagen im gesamten Körper vorhanden sind (sei es im Blut oder in den Genen in jeder Zelle), dass sie aber in codiertier Form und mit Verzögerung auf den sich entwickelnden Keim übertragen werdem. 
What is one to say? I myself have sometimes ventured to suggest some-limited-respects in which philosophy of biology might learn from Aristotle; but faced with an extravaganza like this, I am afraid I find it more appropriate to try to understand a thinker of the past in his own terms and his own context, rather than to try to relate his concerns to ours.

Two more limited issues touched on in our texts remain to be mentioned. A question is sometimes raised about the relation of Aristotle as a biologist to the theory of evolution-even though, as far as I could tell, the issue had been settled long ago. Thus Lennox points out that evidence in favor of an evolutionary view is hard to come by, and for Aristotle to have embraced it would have been wildly speculative (p. 178). Other things being equal, it is entirely reasonable that a natural historian, whose job it is to tell one sort of critter from another, should suppose his carefully distinguished subjects to stay put. That was still what Cuvier emphatically believed in the first decades of the nineteenth century, and so did the young Richard Owen, as he declared in his 1837 Hunterian lectures. Still, as Aristotle's defenders have successfully rescued him from the taint of "typological essentialism," they may also want to keep him from being branded an anti-evolutionist. Thus David Balme suggested that, although Aristotle had no evidence for evolution, he was not tied to the conception of a "fixity of species." To the contrary, in an essay based chiefly on a careful reading of crucial passages in the Metaphysics, Lennox argues that Aristotelian species are indeed eternal; since, in Aristotelian nature, individual members of kinds have originated from individuals with a form identical to theirs, and will continue to do so indefinitely. At the same time, he holds that those forms themselves are not eternal. Each individual sparrow or frog or human being is characterized by the same form as every other, yet the form itself cannot be said to be eternal, even though there always have been and always will be instances of it. Except as an expression of opposition to separate Platonic forms, I am not sure I know what this means. However, Lennox's reading of Aristotle's thoroughly non-evolutionary stance is plain enough. ${ }^{7}$

6. David Balme, Aristotle's De Partibus Animalium I and De Generatione Animalium I (with pages from II, 1-2), Oxford: Oxford University Press, 1972, p. 97 cited by Lennox, p. 154.

7. This essay is placed immediately after Lennox's remark about rendering eidos consistently as form and genos as kind. His reversion to the more traditional usage, with species and form distinguished, thus makes the argument, at least for this reader, difficult to follow. It would take me too far afield to go into detail, but he speaks, for example, of a species as continuing to replicate its form (p. 155): a form continuing to replicate its form? True, this essay stems from 1981-2, while the introductory remarks were presumably written in 1999. Still, given the coherent whole that the volume vaunts itself to be, this is 
In startling opposition to this well-established view is the thesis enunciated by Arbogast Schmitt in his contribution to the Kullmann-Föllinger volume, "Verhaltensforschung als Psychologie" (pp. 259-285). In Aristotle, together with Plato, he takes the scala naturae as "a sequence of steps of development from the very simplest forms of life to the intellect of man, which creates ever new qualities . . . in unbroken fashion, continuously, and in such a way that the higher stage assimilates the lower to itself and reproduces it in new form" (" . . . dem Gedanken einer "scala naturae', . . . einer Stufenfolge der Entwicklung von allereinfachsten Formen des Lebens bis hin zum Intellekt des Menschen, die in bruchloser Weise, kontinuierlich, in gleitenden Übergängen . . . immer neue Qualitäten schafft, und zwar so, dass die jeweils höhere Stufe die niedrigere in sich aufnimmt und in neuer Form reproduziert" p. 262). At least, unlike Kullmann with his "Aristotelian genetics," Schmitt goes on to admit that his ancient thinkers do not advocate "a purely genetic theory of descent" ("eine rein genetische Descendenztheorie" Loc. cit.). For Aristotle in particular, he explains in a pair of footnotes why such an historical reading of the "scale of nature" is demanded. It seems to be the nature of Aristotelian matter in its relation to form (or species), that makes this necessary: "In the sense of the Aristotelian concept of matter, there can be absolutely no unalterability of natural-empirical species" ("Eine Unveränderlichkeit natürlich-empirischer Arten kann es im Sinn des Aristotelischen Materiekonzepts überhaupt nicht geben" p. 263, n. 26) Since form controls matter, it is not clear on the face of it why this should be so; in fact, as Schmitt concedes, it appears to most students of Aristotle that it is the contradictory of his pronouncement that obtains. Schmitt assures his readers, however, that the truth of this heterodox opinion has been established by Christian Pietsch in an article called "Biologische Evolution und antike Ideenlehre." Then, from this instability it follows, Schmitt declares, that Aristotle must accept some kind of evolutionary theory, though not one driven "by a blind mechanism of selection" (p. 262, n. 25). Apparently it is the development of soul that directs his evolutionary history. Faced with Kullmann's book and Schmitt's article, one can only remark that there are some German classicists who hold very strange views in the history of science.

Finally, the issue of Aristotle's attitude to taxonomy is touched on in several places in these volumes. Due in part at least to the work of David

disturbing. I may add that I am struck by the extent, and precision, of Lennox's use here of texts from the Metaphysics. This is not just a question of applying the Posterior Analytics to the biological works.

8. In Klaus Döring and Georg Wöhrle, eds., Antike Naturwissenschaft und ihre Rezeption, vol. IV, Bamber, 1994, pp. 17-30. 
Balme and Pierre Pellegrin, it is by now pretty generally conceded that Aristotle was not a systematist: he was not trying in his biological works to provide an over-all classification of animal species, genera, families, and so on. Lennox, for example, says he has gradually come round to this view. On the other hand, Lloyd finds in some passages of the Parts of Animals support for the notion that Aristotle "did indeed have in mind, as his goal, a comprehensive and exclusive system, not merely a description of non-exclusive groupings," although he admits that many modern commentators now deny this (p. 56). And in discussing the way in which in the Politics Aristotle likens the types of political constitutions to natural kinds, he refers again to that "highly controversial" question, on which he feels some sympathy for what appears to be the losing side (p. 195). Kullmann, of course, taking species to be an absolute term, can be entirely confident about Aristotle's systematic intentions (pp. $168 \mathrm{ff}$.), even if he has earlier suggested (p. 101, n. 140) that in practical terms a complete taxonomy of animals would be difficult to carry out. However, as I mentioned earlier, I find Lennox's (and Balme's) reading of the relevant texts sufficiently authoritative so that I can ignore Kullmann's opposition. At the same time, Lloyd's hesitation to accept the new orthodoxy does seem worth mentioning. 